\section{Profitable frontiers}

\section{Daniel S. Greenberg}

The Golden Helix: Inside Biotech Ventures. By Arthur Kornberg. University Science Books: 1995. Pp. 287. \$28, £24.95. Distributed in Europe by W. H. Freeman.

THE Nobel laureate Arthur Kornberg does not hoard his spears in this candid, acerbic memoir of an academic scientist's venture into industry-financed research. Ravenous Wall Street investors, dense

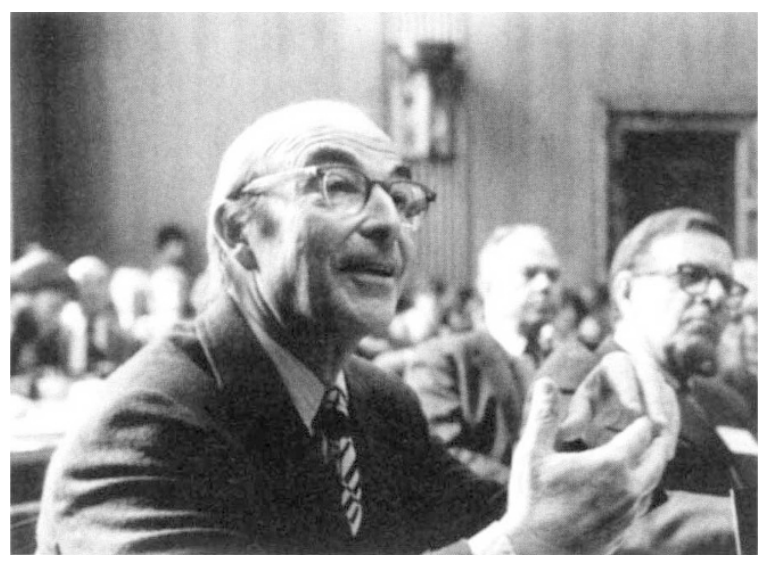

abrasive manner" in which board meetings were chaired by Walter Gilbert, a 1980 Nobel prizewinner. Gilbert, he reports, made "daily phone calls" to the chief executive officer, Robert Luciano, "berating the ineptitude of the Schering-Plough staff and the inadequacy of the company's operations".

Kornberg finds no end of targets. Scientists at the booming Genentech start-up company were "distracted by concerns about how best to enjoy and invest the bonanza profits pouring in from their ownership" of stock. And from his perspective as a witness in litigation challenging patent rights for the polymerase chain reaction (PCR) technique, Kornberg deplores 뭄 "inappropriate commercial exploitation of knowledge that was paid for [by], and belonged to, the public".

Although corporate and academic stumbling and inanity are his backdrop, Kornberg is mainly concerned with telling the tale of a successful marriage of fundamental research and industrial money. Blessed with foresight and good luck, he says, he and his colleagues successfully melded corporate support Talking candidly: Arthur Kornberg, with Lewis Thomas (right). and university-style, open basic research in what he proudly describes and lauds as an exceptional creation: the DNAX Research Institute of Molecular and Cellular Biology, Inc., which, after a parched period, became a well-financed subsidiary of Schering-Plough. Focused on the molecular biology of $\mathrm{T}$ cells and cytokines, DNAX, founded in 1980, is described by Kornberg as "a small institute, remote from the imperatives of product development and marketing and given the freedom to innovate".

In these admirable respects, he asserts, it is a rarity in pharmaceutical research, as well as a miraculous survivor, given the ravenous demand for products and cash flow in the profit-starved biotechnology industry. Kornberg salutes the scientific and marketplace achievements of other biotech companies, notably Amgen and Genentech. DNAX has yet to produce an economic blockbuster, he acknowledges, but he expresses confidence that therapeutic value and riches are sure to ensue from Schering-Plough's development of DNAX's pioneering research on the powerful interleukin IL-10.

Steeped in the values and culture of academic fundamental research, Kornberg urges recognition of the continuing intellectual debt that the pharmaceutical industry owes to university-based science. "The industrial sector", he states, "must be reminded that the concepts, techniques, and practitioners of biotech ties, he writes, were heightened by "the ventures and biotechnology driven pharmaceutical firms all came from basic academic research. As technologies proliferate and gain in sophistication, their scientific foundations are submerged and forgotten." And he warns against "illusions that basic research can be left to industry". "In fact", he declares, "more than 90 percent of such research has been, in the past, and must be in the future, done in university and other academic settings, requiring massive support to the tune of billions of dollars from the taxpayer through the federal government."

Kornberg's unexceptionable views on the wellsprings of scientific knowledge are embedded in a smartly written work that will reward readers in academe and industry. One puzzling dissonance, however, must be noted by this otherwise admiring reviewer. Yes, of course, as Kornberg writes, the indispensable billions for basic research in the United States must be provided by the taxpayers through the federal government. It is jarring, then, to find that elsewhere in The Golden Helix, Kornberg reports that Zaffaroni "incorporated DNAX in the Isle of Jersey, one of the Channel Islands, a maneuver designed to save taxes on future earnings as had been achieved by making Syntex a Panamanian company". No comment.

Daniel S. Greenberg is editor and publisher of Science \& Government Report, 3736 Kanawha Street NW, Washington DC 20015, USA.

\section{Betrayer of truth}

\section{Anthony Snodgrass}

Schliemann of Troy: Treasure and Deceit. By David A. Traill. John Murray: 1995. Pp. 365. £19.99.

DAVID Traill would hardly claim to be a detached observer of the excavator of Troy and Mycenae, his quarry for the past 15 years. This is the third book he has published, jointly or alone, on Heinrich Schliemann: with his painstaking search through diaries, newspapers, catalogues and weather-reports, he would make a great prosecuting counsel. $\mathrm{He}$ has proved beyond argument that Schliemann, if not a complete psychopath, was an unsavoury character, egocentric, a bully to the weak and a sycophant to the powerful, and, above all, profoundly dishonest.

Schliemann was not just economical with the truth: he purveyed lovingiy crafted, circumstantial falsehoods especially but (alas) not only about his personal life. He was sometimes caught out in his lifetime, which explains the contempt in which some (not all) of his learned contemporaries held him, and 
their unavailing, because misdirected, attempts to discredit his findings. The question today, a century and a quarter after his great discoveries began, is: how much does this still matter? Traill's case is that it matters very much. Once we realize that any statement of Schliemann's about the find-circumstances, location, manner and date of discovery of any portable object that he published (or even noted in his diaries) may be either a deliberate lie or a careless error, then the assemblages or (as he called them) treasures which did most to make him famous begin to fall apart.

In 1984, Traill showed that this was beyond doubt true of one of his most famous discoveries, the Early Bronze Age "Treasure of Priam", allegedly found on 31 May 1873 at Troy, presumably in one of the three or more different locations that Schliemann at different times attributed to it. Schliemann was careless enough to have illustrated some of the objects, later included in "Priam's Treasure", in the finds of earlier seasons. We also know that throughout his campaigns he was intermittently buying objects from local inhabitants. There is a suspicion that some of these may also have found their way into his assemblages.

In two chapters, Traill advances parallel arguments about the even more remarkable discoveries of November 1876, when Schliemann was excavating the Shaft Graves at Mycenae. The contents of these tombs have stood, ever since, as a landmark at the beginning of the Mycenaean civilization, belonging not (as Schliemann thought) to the time of the Trojan War, but three or four hundred years earlier, in the sixteenth and even

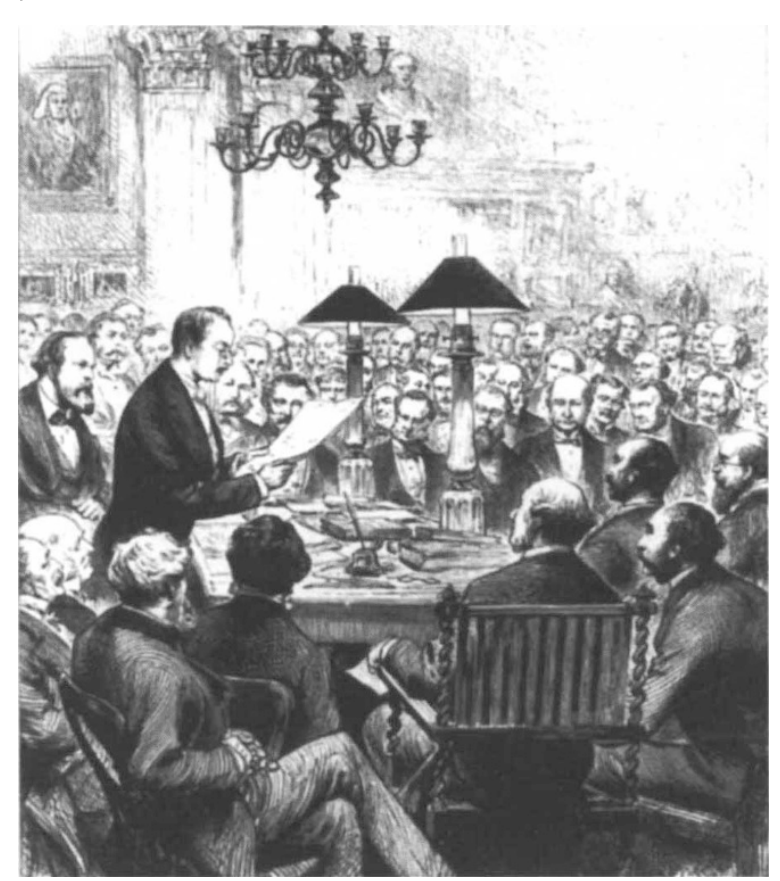

Telling it as it isn't: Schliemann speaking to the Society of Antiquaries at Burlington House, 1877. the seventeenth centuries BC. The tombs themselves are still there, and there is a reliable witness to the discovery of at least some of the most spectacular finds within them. But the rest? This time the evidence is almost all circumstantial: Schliemann did not repeat the mistake he made at Troy. But his account can be faulted for carelessness in transferring finds from one grave to another and, for the ten days that covered the excavation of the prodigiously rich Shaft Graves III, IV and $\mathrm{V}$, maybe something worse.

The Shaft Graves span only a couple of generations, yet the diversity of style in the finds, even within the same tomb, might suggest a longer span. In at least one case (that of two terracotta figurines "from Shaft Grave I"), later knowledge has shown a definite discrepan-

cy in date, of at least 200 years. Traill argues that, for weeks before the finding of the Shaft Graves, Schliemann had been excavating burials, some of them directly above (and therefore, like the figurines, later than) the Shaft Graves themselves.

Worse still, if there is one find that has become emblematic for Schliemann, and for the prehistoric Aegean generally, it is the moustachioed and searded gold mask, still often and mistakenly dubbed the "Mask of Agamemnon", which duly appears on the jacket of this book. With its up-turned moustache and imperial goatee, it is utterly unlike the other four gold masks found in the same grave and its neighbour why? Traill states that examination of the mask shows the moustache to have been originally shown as drooping: at some point it was "rather crudely" altered. Was this in the sixteenth century $\mathrm{BC}$ or in the 1870 s, between the reigns of Napoleon III and those of Tsar Alexander III and Kaiser Wilhelm II (to name just three rulers that it vaguely recalls)? One would like more confirmation - say, a death- bed confession from the hypothetical goldsmith responsible for this and other work, such as the mass-reproduction of some of the 701 gold discs found only in Grave III. But it is disquieting enough to make one ponder the reality, scale and hom-ogeneity of the "Shaft Grave culture" that has dominated every account of the period since.

Yet Schliemann's discoveries, however much embroidered and added to by his dishonesty, were real enough: the buildings at least, even older than he himself thought them, are there for all to see. Even when we can catch him redhanded 'salting' his discoveries, the intrusive objects mostly turn out to belong to the right period (a point that Traill does not fully face). In the end, for all the damaging points that Traill makes, the abiding source of worry is a different one from his. Schliemann conformed to a type that one recognizes at once from the fringes of any science, or from among its weaker students - ingratiating, exaggeratedly deferential to scholarly reputation, ready to borrow without acknowledgement from other books in his own writing: someone whom, if he laid claim to a momentous discovery, one would instantly assume to have fabricated it. This is exactly how many of his contemporaries thought of Schliemann, and, in the last analysis, they were wrong.

Anthony Snodgrass is at the Faculty of Classics, University of Cambridge, Sidgwick Avenue, Cambridge CB3 9DA, UK. 